\title{
Journal of Information and Technology
}

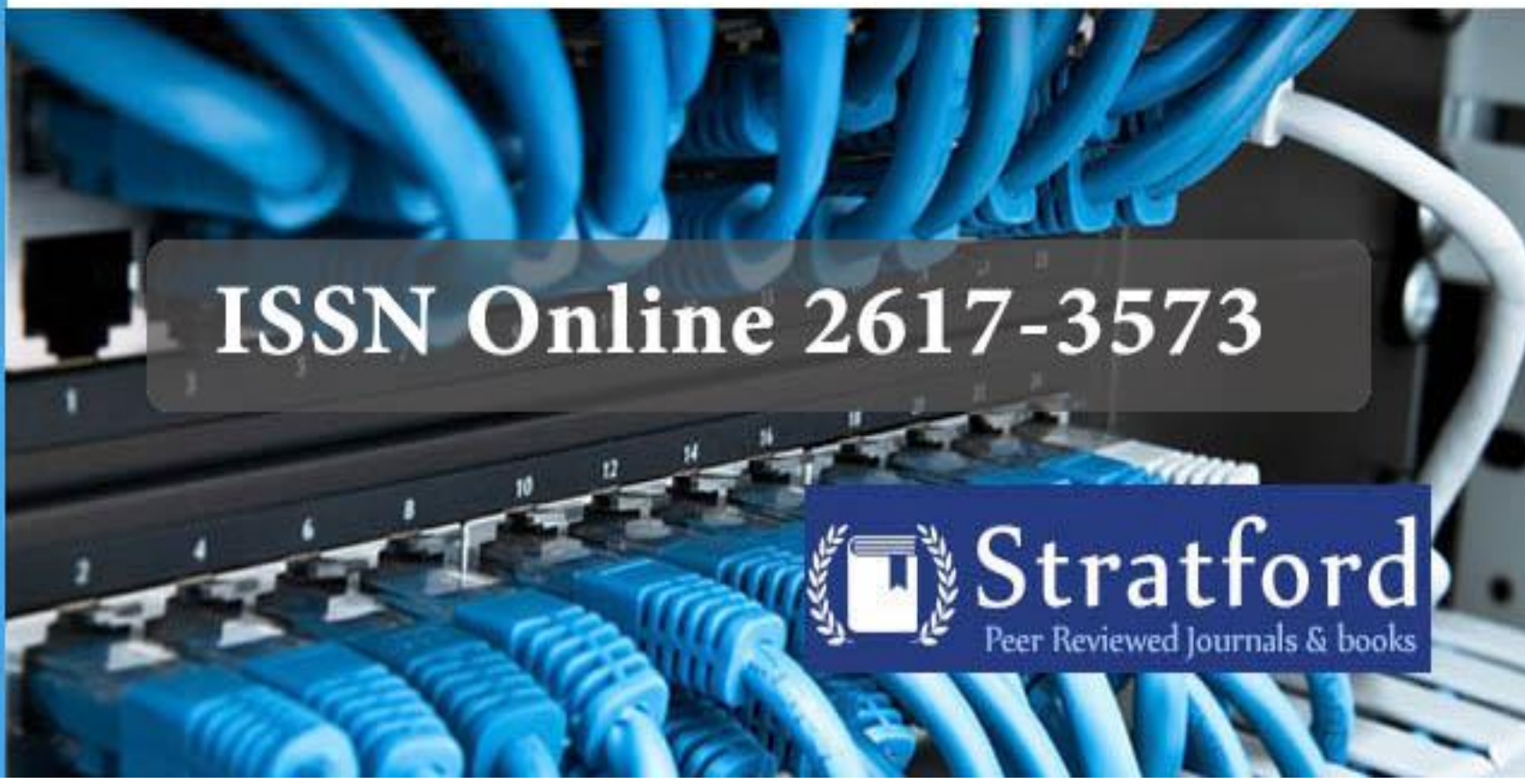

Influence of Information and Communication Technology on Teaching and Learning. A case of Rwanda Polytechnic-IPRC Tumba.

NSABIMANA Camille, MUKAMANA Jeannette, TURINUMUKIZA Maurice \&

${ }^{4}$ UMUGWANEZA Laetitia

ISSN: 2617-3573 


\title{
Influence of Information and Communication Technology on Teaching and Learning. A Case of Rwanda Polytechnic-IPRC Tumba.
}

\section{${ }^{1 * N S A B I M A N A}$ Camille, ${ }^{2}$ MUKAMANA Jeannette, ${ }^{3}$ TURINUMUKIZA Maurice $\&$ ${ }^{4}$ UMUGWANEZA Laetitia}

\author{
${ }^{1,4}$ Assistant Lecturer at Rwanda Polytechnic-IPRC Tumba \\ ${ }^{2}$ Carnegie Mellon University Graduate in Master of Science in Information Technology \\ ${ }^{3}$ University of Kigali Graduate in Master of Science in Information Technology
}

“Corresponding Author’s Email: nsabecamille@gmail.com

How to cite this article: NSABIMANA, C., MUKAMANA, J., TURINUMUKIZA, M. \& UMUGWANEZA, L. (2022). Influence of Information and Communication Technology on Teaching and Learning. A Case of Rwanda Polytechnic-IPRC Tumba. Journal of Information and Technology, 5(2), 1-8. https://doi.org/10.53819/81018102t3032

\begin{abstract}
The advancement and the rapid growth of information and communication technologies (ICTs) have facilitated teaching and learning effectively. Practicing ICT plays a big role in the facilitation, improvement of pedagogy and content knowledge. This study investigates the influence of ICT on teaching and learning in Rwanda polytechnics a case of Rwanda Polytechnic-IPRC-Tumba. The study used mixed methods approach research design and targeted 682 respondents that included 643 students and 39 lecturers. A sample size of 88 respondents of target population was sampled using simple random sampling method. Stratified sampling technique was used to identify students and lecturers. A questionnaire instrument as used to collect data from both students and lecturers. Gathered data were coded and processed by mean of SPSS. Quantitative data was analyzed by means of descriptive statistics and regression analysis, such as percentages, Durbin-Watson, tolerance and VIF. Qualitative data was analyzed thematically harmonized with the objectives of the study. The study findings were reported in summary form using tables. About the findings Durbin-Watson on ICT resources availability, ICT resources usage and users ICT support on teaching and learning was 1.731 and ICT resources scored tolerance of 0.735 and VIF of 1.360, ICT resources usage scored tolerance of 0.533 and VIF of 1.878 and users ICT support scored tolerance of 0.531 and VIF of 1.883 . The study finally concluded ICT had significant influence on ICT capacity in Rwanda polytechnicIPRC Tumba (Rulindo district-Rwanda). Therefore, the ministries of education and Rwanda Polytechnic administrators were recommended to deploy ICT in teaching and learning.
\end{abstract}

Keywords: Information Technologies (IT), Rwanda Polytechnic (RP), Education Sector, ICT (Information Communication Technology), IPRC Tumba 


\section{Introduction}

Information and Communication Technology (ICT) in education has been continuously linked to higher efficiency, higher productivity, and higher educational outcomes, including quality of cognitive, creative, and innovative thinking. ICTs are said to enhance the quality of education in several ways: By increasing learner's motivation and engagement and by facilitating the acquisition of basic skills. Rapid developments in ICTs have driven numerous changes within the academic responsibilities where the methods to be used are advanced. Thus, ICT resources have been looked upon as a tool used to lift the standard of education.

The ICTs have led to many changes in the responsibilities of academics at tertiary institutions as traditional methods of academic performance are often inappropriate. Therefore, ICT resources are seen as a tool to raise the standard of education. Information Technology has recently changed to Information and Communication Technology. The integration of ICT into schools makes it one of the pillars of developed societies in the world. Mukama (2008) shows that the mindfulness and inspiration of utilizing ICT in instructing and learning depend on teachers' ways of handling the technology. Mukama (2008) added that having sufficient practical time and working together to solve the available problems can boost students' active involvement in teaching and learning with ICT. According to Hennessy (2010), current technologies like digital services and new devices are becoming the soul of society in daily life. Such technologies are used in schools, colleges, and university classrooms. Many lecturers use technology hoping that it helps in improving their teaching strategies. Some of the technologies employed include social networking, digital media, and presentation tools with increasing the attention of students and their participation together with the increase in their academic performance or achievement. However, many lecturers or teachers do not embrace new technologies as they lack technologies' instructions.

The Government of Rwanda (GoR) is committed to improving science and technology education, with concrete initiatives addressing underdeveloped skills in all areas of science and technology, as well as limited resources in teaching institutions, ICT should be utilised to promote quality learning in science and technology education in all subject areas as it is an energetic tool for development (UR, 2017). The focus on ICT in the education sector includes harnessing creativity, improving educational quality, expanding access to learning methods and resources, including new categories of learners, promoting communication and teamwork skills, and increasing the ability of all those involved in education. Learning and the utilization of ICT in Rwanda can be accomplished, according to Mukama (2009), through an examination of students' and teachers' interaction and behaviour, which constrains both students and lecturers. The confinements incorporate learning conditions that can help or prevent recently qualified instructors or understudies learning in ICT-based settings, the sorts of talks understudies and instructors in little bunches take an interest in whereas taking an interest in computer-supported collaborative learning exercises, and the setting communicated in recently qualified teachers' or understudy teachers' accounts of learning in computer-supported exercises, and the learning conditions for dialect brought to the think about of web-based writing in little bunches. 
Rwanda is making a huge effort in education to make its brilliant future. Since the excessive population proportion in Rwanda is young, the country is lightening every young human to be involved in education or different education colleges put in place for them. Many competitions on ICT in special areas like agriculture, online services, robotics, are organized. The country additionally has mounted polytechnics to increase the level of training from one factor to another.

\section{Literature review}

\subsection{ICT integration in education}

There has been a high level of investment in ICT in education over a prolonged period throughout the 'developed world' (Twining, 2002). Interest in ICT in education in England stretches back to at least the mid-1960s, when the original National Council for Educational Technology was first formed (CET, 1975). At this time the main focus was often on further and higher education rather than on schools; later there was expansion to the schools starting with secondary then primary schools through government funding. Twining (2002) outlines some of the policies employed by government in England in order to meet the government targets for ICT in education. Funding was made available for; the National Grid for Learning (NGfL), connecting every school in the country to the Internet; providing additional computer equipment for every school; training every teacher in state schools in the United Kingdom to make effective use of ICT as a tool to support teaching: cutting bureaucracy in schools through the use of ICT and setting up of a number of Centers of Excellence for IT and High Technology training and Skills Challenge projects (Twining, 2002).

Some typical characteristics of these countries are as follows: almost all classrooms are equipped with computers and other ICT tools; the student/computer ratio is high; internet access is available in all schools; curriculum revision ensures nationwide ICT integration; delivery of education is increasingly online (UNESCO, 2008). Integration of ICT in schools in developing countries especially in Africa was slow and uneven as indicated by a sample selection of African countries through NEPAD (New Partnership for Africa Development) e-schools project which provides some estimates of numbers of the schools reached with computers (Farrel \& Shafika, 2007).

Table 1: Computer Penetration Ratios at Schools African Countries (2007)

\begin{tabular}{llll}
\hline Country & Number of Schools & Schools withComputers & $\begin{array}{l}\text { \% Of Schools with } \\
\text { Computers }\end{array}$ \\
\hline Egypt & 26,000 & 26,000 & $100 \%$ \\
Ghana & 32,000 & 800 & $2.5 \%$ \\
Mozambique & 7,000 & 80 & $1.1 \%$ \\
Namibia & 1,519 & 350 & $22.1 \%$ \\
South Africa & 25,582 & 6,651 & $22.6 \%$ \\
\hline
\end{tabular}

Source: NEPAD e- schools project

Many governments have realized the positive impact of ICT in education henceforth developed national ICT policies and ICT education strategies to guide on its integration for maximum benefits. According to the infoDev report, quoted in Farrell and Shafika (2007), ICT policies in 
the East African Community began taking shape in the early 2000s; there had been an increase in unregulated use of ICTs that prompted the need for governments to offer direction in the use of these technologies.

Rwanda promulgated its national ICT policy in 2000; it is based on a document that was released in 1999 for national debate and consultation. In 2000 just one school in the country had a computer, six years later over half of primary and secondary schools have been equipped with hardware, over 2,000 teachers had received ICT training, and all public schools are expected to join the information superhighway by the end of 2008. Already, out of the 400 secondary schools has been fully equipped, some of them having wireless Internet access. The national School Net project included in the NICI-2010 plan was intended to be the vehicle for school Connectivity (Glen Farrell, 2007).

\subsection{Technology Acceptance Model}

This research was based on Technology Acceptance Model (TAM) by Davis et al. (1989); and Venkatesh et al. (2003). Since the mid 1970's, quite a number of researchers have put much interest on factors that explain the use of different ICTs technologies. Technology Acceptance Model represents one of the explanatory models having most influenced theories of human behavior (Venkatesh, Morris, Davis, \& Davis 2003). The primary aim of TAM was to identify the determinants involved in computer acceptance in general; to analyze a variety of information technology usage behaviors; and finally, to provide a penurious theoretical explanatory model (Davis, Bagozzi, \& Warshaw, 1989). It is rooted in social psychology and draws on Fishbeins and Ajzen's reasoned action model (1975) which implies that the intent to produce a behavior depends on two basic determiners: Attitude towards behavior and Subjective norms.

Subjective norms refer to the reasons for producing a certain behavior or not, while attitude towards ones' behavior refers to the positive or negative value the individual attaches to the facts of portraying the behavior. According to TAM, attitude would be a direct predictor of intention to use technology which in turn would predict the usual usage of technology Figure 1 shows the pictorial representation of TAM.

\section{Figure 1: Technology Acceptance Model}

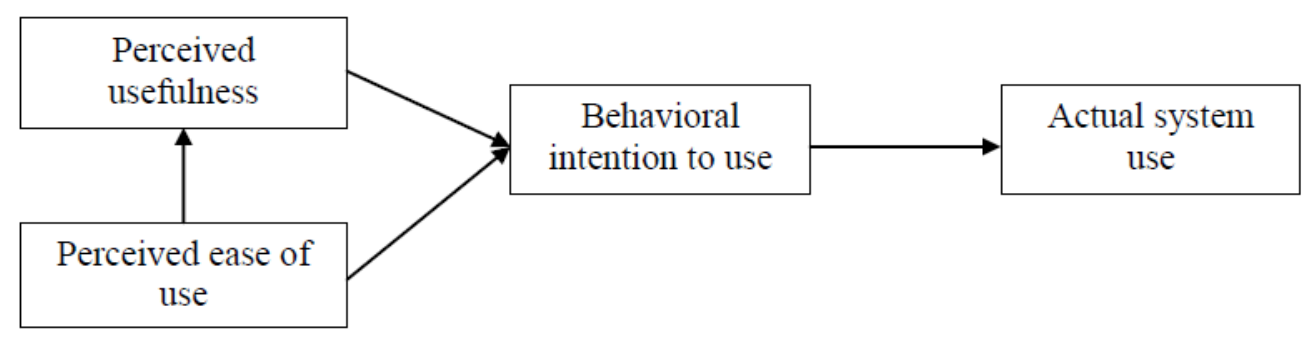

Source: (Davis et al., 1989; Venkatesh et al., 2003)

Davis and Venkatesh, (1996) argued that attitude would not plays a big part but rather that perceived ease of use (expectation that a technology requires minimum effort) and perceived usefulness (the opinion that use of a technology can enhance performance of a task at hand) 
would determine intension to use a technology. Venkatesh (2000) adds that the TAM is a good model but so far it does not help us understand and explain the acceptance of a technology in a way that can promote the development of a strategy to have a real impact of the usability and acceptance of the technology. Venkatesh (2000) therefore proposed a modified model to the TAM by adding the following four personal anchoring factors as determinants to perceived ease of use: Computer self-efficacy, perception of the external control, anxiety towards computers and Computer playfulness.

The two adjustment-based factors have come up with growing experience namely: Perceived enjoyment and the objective usefulness. These anchors represent general beliefs about computers and their use. Furthermore, they would seem to play an important role in forming opinion of perceived ease of use of a new system.

\section{Methodology}

This study used the mixed approach of research design. The target population was lecturers and students with information about ICT at IPRC-Tumba. In the academic year 2020-2021, IPRCTumba had 643 students and 39 lecturers who give the total population of 682. This number gives very large population, thus sampling in this situation was practically considered during this study because studying a whole population was intense work, due to the time would take to be accomplished, financial means to accomplish the task thus the researcher selected students and lecturers are manageable to deal with. The Slovin's formula gives an easy way to determine the size of a sample. The researcher used a sample of 132 respondents for getting more accurate information. Sample was selected by using simple random sampling technique as indicated by table 2.

Table 2: Population sample

\begin{tabular}{lllll}
\hline Category & Population & Sample & Percentage & Sampling technique \\
\hline Students & 643 & 112 & $85 \%$ & Simple random sampling \\
Lecturers & 39 & 20 & $15 \%$ & Simple random sampling \\
Total & 682 & 132 & $100 \%$ & \\
\hline
\end{tabular}

The researcher used simple random sampling technique to select sample as both lecturers and students at IPRC-Tumba have information about ICT. 


\section{Data analysis, findings, and discussions}

The following section presents the results of current study on investigating the influence of Information and Communication Technology on teaching and learning, a case of Rwanda Polytechnic-IPRC Tumba.

\subsection{Analysis of effect of ICT on Teaching and learning success}

To analyze the effect of ICT on Teaching and learning success at IPRC-Tumba, the respondents were asked on how they rate the effect ICT on Teaching and learning success at IPRC- Tumba and the researcher use regression analysis to analyze the effect of independent variables on dependent variable as indicated in table 3 and table 4.

Table 3: A model summary box analysis of effect of ICT on teaching and learning Model Summary ${ }^{\text {b }}$

\begin{tabular}{lllll}
\hline Model & $\mathrm{R}$ & R Square & Adjusted R Square Std. Error of theDurbin-Watson \\
Estimate
\end{tabular}

a. Predictors: (Constant), ICT resources availability, ICT resources usage, Users 'ICT supports.

b. Dependent Variable: Teaching and learning.

Table 4: Coefficients box analysis of effect of ICT on Teaching and learning Coefficients $^{\text {a }}$

\begin{tabular}{|c|c|c|c|c|c|c|c|}
\hline Model & $\begin{array}{l}\text { Unstan } \\
\text { Coeffic }\end{array}$ & $\begin{array}{l}\text { Idardized } \\
\text { cients }\end{array}$ & $\begin{array}{l}\text { Standardized } \\
\text { Coefficients }\end{array}$ & & Sig. & $\begin{array}{l}\text { Coll } \\
\text { Stati } \\
\end{array}$ & \\
\hline & $\overline{\mathrm{B}}$ & Std. Error & Beta & & & Tole & $\mathrm{eVIF}$ \\
\hline (Constant) & 20.647 & .9 .530 & & 2.167 & .140 & & \\
\hline resource & es.295 & .154 & .333 & 1.911 & .067 & .735 & 1.360 \\
\hline avail & & & & & & & \\
\hline ICT $r$ & .135 & .117 & .150 & 1.154 & .253 & .533 & 1.878 \\
\hline Users 'ICT supports & 205 & .130 & .205 & 1.581 & .119 & .531 & 1.883 \\
\hline
\end{tabular}

a. Dependent Variable: Teaching and learning.

The Table 3 Shows that the Durbin-Watson was 1.731 and table 4 also shows that tolerance was 0.735 and VIF was 1.360 on ICT resources availability, tolerance was 0.533 and VIF was 1.878 on ICT resources usage, tolerance was 0.531 and VIF was 1.883 on users ICT supports. By using the Durbin-Watson analysis, the Durbin-Watson is the value between 0 and 4 . In case the value is less than to 2 there is a positive autocorrelation between independent variables and dependent variable which is the case of this study. By using collinearity statistics analysis, the assumption to be met VIF scores to be well below 10, and tolerance scores to be above 0.2 . 


\section{Conclusion}

Based on the above findings, the ICT capacity at IPRC-Tumba was not yet completely reached to intended capacity as still there was same challenges like inadequate internet bandwidth, inadequate appropriate ICT infrastructure, poor access to software for lecturers and students, Poor access to software for lecturers and students, inadequate appropriate administrative support, inadequate knowledge/skills for ICT integration in teaching and learning, inadequate in-service and re-training in ICTs. Even though there were these challenges, it was discovered that ICT had a significant influence on teaching and learning at IPRC-Tumba.

\section{Recommendations}

This study discovered that ICT has a significant role on Teaching and Learning. Therefore, the following are recommended:

1. To the ministry of education MINEDUC: As the in charge of education sector in a country, it should put much emphasize in investigating in ICT in Rwanda polytechnics by financing the availability of internet bandwidth, printers, scanners, photocopiers, software etc., and prepare enough trainings to RP lecturers about ICT.

2. To Rwanda Polytechnic administrators: The researcher recommends Rwanda Polytechnic (RP) coordinators that they should encourage the accessibility of e-library and e-learning in IPRCs and empower the ICT trainings for lecturers.

3. Areas for further research: The researcher recommends the future researchers to improve this research by assessing the influence of ICT on pandemic restriction in Rwanda polytechnic.

\section{REFERENCES}

Bryman. (2008). Social Research Methods, 3, illustrated. Oxford University Press.

CET. (1975). Two years on: The national development programme in Computer assisted learning. London: The council for educational technology (CET).

Cohen et al. (2011). Research methods in education. British journal of education, 42(5), E110E110.

Davis, F.D. (1986). A technology acceptance model for empirically testing new end-user information systems: Theory and results. Massachusetts, United States: Sloan School ofManagement, Massachusetts Institute of Technology.

Davis, F. D. (1989). Perceived usefulness, perceived ease of use, and user acceptance of information technology. MIS Quarterly, 13(3), 319-340.

Davis, F. D., Bogozzi, R., P., \& Warshaw, P., R. (1989). User acceptance of computer technology: A comparison of two theoretical models. Management Science, 35, 9821003.

Davis, F. D. (1993). User acceptance of information technology: system characteristics, user perceptions and behavioral impacts. International Journal of Man-Machine Studies. 38, (3), 475-487 
Davis, F. D., \& V. Venkatesh. (1996). A critical assessment of potential measurement biases in the technology acceptance model: Three experiments Internet. J. Human-Comput. Stud. $4519-45$.

Farrel G. \& Shafika I. (2007). Survey of ICT and Education in Africa. A summary Report, based on 53 country survey. Washington, DC: InfoDev/World Bank.

Fishbein, M., \& Ajzen, I. (1975). Belief, attitude, intention, and behavior: An introduction to theory and research. Reading, Mass; Don Mills, Ontario: Addison-Wesley Pub. Co.

Hennessy, S. (2010). Developing use of ICT to enhance teaching and learning in East African Schools. Centre for Commonwealth Education. https://explorable.com/populationsampling

Idrus, A. B., \& Newman, J. B., 2002. Construction related factors influencing the choice of concrete floor systems. Constr Manage \& Econ, 20(1), 13-19.

Jebba, A. M. (2010). Survey of accessibility and usage of information and communication technology among students of technical education in tertiary institutions in Niger state, Nigeria New Media and Mass Communication (Online) 3. Retrieved from www.iiste.org on $2^{\text {nd }}$ April 2021

Mukama, E. (2008). Students' interaction with Web-based literature: towards dissolution of language boundaries. International Journal of Knowledge and Learning. 478-495.

Mukama, E. (2009). The interplay between learning and the use of ICT in Rwandan student teachers' everyday practice," Journal of Computer Assisted Learning. 539-548.

Mukama, E. (2014). Bringing technology to students' proximity: a sociocultural accountof technology-based learning projects. International Journal for Research in Vocational Education and Training. 125-142.

Twining, P. (2002). Enhancing the Impact of Investments in "Educational" ICT (PhD Thesis). The Open University, Milton Keynes. Retrieved from http://kn.open.ac.uk/public/document.cfm?documentid=2515

Ubulom, W.J., Enyekit, E.O, Onuekwa, F.A \& Amaehule, S. (2011). Analysis of Information and Communication Technology (ICT) Accessibility and Utilization in Teaching of Business Studies in Secondary Schools in Andoni Local Government Area, Rivers State, Nigeria. International Association for Teaching and Learning (IATEL) Proceedings of the 2011 International Conference on Teaching, Learning and Change.

UNESCO. (2002). Information and Communication Technology in Education-A Curriculum for Schools and Programme for Teacher Development. Paris.

Vajargah, K. F., Jahani, S., \& Azadmanesh, N. (2010). Application of ICTs In Teaching And Learning At University Level: The Case Of Shahid Beheshti University. The Turkish Online Journal of Educational Technology 9(2) 112-119

Venkatesh, V., Morris, M.G., Davis, F.D., \& Davis, G.B. (2003). User Acceptance of Information Technology: Toward a Unified View. MIS Quarterly, 27, 425-478.

Venkatesh, V. \& Bala, H. (2008). Technology Acceptance Model 3 and a Research Agenda on Interventions. Decision Science, 39 (2), 273-312. 